\title{
The Importance of Universal Design for the Disabled in Public Buildings: A Public Building in Northern Cyprus as a Case Study
}

\author{
Ümran Duman', Kozan Uzunoğlu, ${ }^{2, *}$ \\ ${ }^{1}$ Faculty of Architecture, Near East University, 99010, Near East Avenue, Lefkoşa, North Cyprus \\ ${ }^{2}$ Faculty of Architecture and Engineering, Bahçeşehir Cyprus University, 99010, Bahçeşehir Cyprus University Alayköy Campus, \\ Lefkoşa, North Cyprus
}

Received February 15, 2021; Revised March 5, 2021; Accepted April 22, 2021

\section{Cite This Paper in the following Citation Styles}

(a): [1] Ümran Duman, Kozan Uzunoğlu, "The Importance of Universal Design for the Disabled in Public Buildings: A Public Building in Northern Cyprus as a Case Study," Civil Engineering and Architecture, Vol. 9, No. 3, pp. 690-707, 2021. DOI: 10.13189/cea.2021.090312.

(b): Ümran Duman, Kozan Uzunoğlu (2021). The Importance of Universal Design for the Disabled in Public Buildings: A Public Building in Northern Cyprus as a Case Study. Civil Engineering and Architecture, 9(3), 690-707. DOI: 10.13189/cea.2021.090312.

Copyright $\odot 2021$ by authors, all rights reserved. Authors agree that this article remains permanently open access under the terms of the Creative Commons Attribution License 4.0 International License

\begin{abstract}
It is essential that public buildings, which have an important place in the whole city and are open to every one's use, designed with the concept of universal design. Universal design; It aims to make standard designs for all groups of people living in a society with different characteristics, regardless of their physiological characteristics, age, gender, social, economic, and educational level. The design and use of public buildings, which are sometimes the city's symbol, sometimes the space that the citizens add color to their lives, and sometimes the facilities where services are received, are essential for the city's identity and the citizens. In this article, the concepts and principles of universal design were defined; the importance of anthropometry and ergonomics in universal design and its historical development were also discussed. As a part of the city, the universal design approach principles have been studied to design accessible, navigable, and accessible buildings together with the city. The legislation having a significant role in shaping the buildings and physical environment has also been discussed and interpreted within this scope. With this study, it has been revealed that "approach to building" (urban level), "circulation within building" (building level), and "reaching services in spaces" (space level) criteria, which are the primary approach criteria of universal design, coincide with the approach introduced in transforming the
\end{abstract}

"user system" into a "building system". Thus, a criteria-based building evaluation form was created to evaluate many public buildings' design following universal design principles. From this point of view, the most used public building of Northern Cyprus has been comprehensively studied. The building's internal organization and its immediate surroundings have been examined and suggestions made within the framework of universal design principles.

Keywords Universal Design, Design for Everyone; Equal Use, Public Space, Public Buildings

\section{Introduction}

Many people with different characteristics live in the world. While designing common environments and products used by various individuals, instead of making different designs for each individual; the design method that aims to create standard designs suitable for many individuals is called universal design. Regardless of different language, religion, race, or gender; considering the various stages of people's life such as childhood, youth, pregnancy, and old age, making standard designs for 
individuals with different characteristics by paying attention to their congenital or mental or physical disability at some point in their life is called universal design. For determining whether the designed product or environment is suitable for universal design, no checklist has been created, and no rules have been defined. Principles have been described to explain the relevant design concept and ensure its adoption. To make the designs for everyone, not only the anthropometric measurements of ordinary people without handicaps but also the measurements of individuals of different genders, ages, or need of wheelchair use were considered. After World War II, an increase in the population of disabled people was observed in many parts of the world, especially in America. The place of the disabled in the society has started to be considered significant. By the effect of these developments, concepts such as barrier-free design have emerged in many countries. Although the designs made especially for the disabled in the past seem positive, their target audience has become uncomfortable over time. Instead of creating special arrangements for the disabled, the universal design concept, which aims to design for everyone by including the disabled among the vast user mass, was used for the first time in 1985 by American architect Ronald L. Mace [1]. Later, design principles were determined by Mace and his colleagues.

The latest version of the universal design principles and the most understandable form that provides information to the designer, which is still in use today, was published on April 1, 1997. Universal design is defined by WHO in World Report On Disability as "A process that increases usability, safety, health, and social participation, through design and operation of environments, products, and systems in response to the diversity of people and abilities" [2]. Universal design principles; equitable use, flexible use, simple and intuitive use, perceptible information, tolerance for error, low physical effort, approach, and enough space for use (size and space for approach and use) [3]. Later on, these principles that are open to improvement, three new principles have been added: the individual's environmental satisfaction (adding to human delight), functional and aesthetic integration, social cohesion and participation. The universal design concept is used by many disciplines such as urban design, landscape design, architectural design, interior design, industrial design, fashion design, graphic design, information technology, and web design. The aim is to design products that everyone can use, open or closed spaces, environments, tools, and furniture.

According to Salmen [4], the increase in universal design applications is directly proportional to the increase in the knowledge of designers about human needs and skills. Knecht [5], one of the researchers who defined universal design, states that design for everyone is not a specific goal, but instead creates a framework for generating solutions. Emphasizing that universal design is a worldwide movement, Knecht; underlines that it targets the widest range of users in environmental, product and communication design. Liu and Hou [6] emphasized that universal design not only improves the quality of life of individuals, but also supports the progress of civilization and the development of social cohesion in society, and states that there are components of inclusiveness, convenience, self-confidence, choice, economy and comfort on the basis of this design principle [7]. Julienne Hanson [8] compared the special designs for the disabled with the universal design and mentioned the social benefits of designs made without any privilege and at the same time excluding anyone.

Accessibility is also essential for high-rise buildings and historic buildings used as public buildings. A qualitative case study was done in a university campus, which examined the compliance of vertical accessibility components in two high-rise buildings with universal design strategies to identify areas for further improvements in promoting social inclusion in educational environments [9]. Kusnierz-Krupa discussed the accessibility in historical buildings in her study, which examined a palace with an outstanding cultural value, functioning as Social Welfare Home. By this research, Kusnierz-Krupa wanted to draw attention to the remodeling and modernization of historical buildings [10]. The Preservation Brief prepared by Jester and Park introduces the complex issue of providing accessibility at historic properties and underlines the need to balance accessibility and historic preservation. The brief guides in evaluating the historic properties to offer the highest level of accessibility while minimizing changes to historic materials and features [11].

\section{Design Criteria of Public Buildings}

Public buildings are the buildings that reflect the social, cultural, and economic status of the society. These buildings, which are open to the public and used by everyone, are designed with social identity. Throughout history, people's tendency to come together and socialize together, the change of lifestyles has also caused changes in the design of public buildings. Public buildings, influenced by the period's architectural styles, were designed not to target a specific part of the users as they are open to everyone in every period.

Contemporary societies with an increasing quality of life over time started to demand more comfortable and reliable buildings. Public buildings accessible to everyone have importance considerations on urban level provided in the city where they are located. The design of public buildings should be suitable for everyone's accessibility in every level of design. Therefore, "approach to building", "circulation within building", and "reaching services in spaces" must be organized appropriately. 


\subsection{Approaching to Public Buildings}

Approaching to public buildings means that all individuals living in the city can access all of the town's public services. This is the most natural right of every individual sharing the city. It is an indispensable component of urbanization, participating in urban decisions and feeling belonging to that place [12].

Different types of users live together in society. According to the World Health Organization (WHO) statistics, the rate of disabled people in any country is $10 \%$. The United Nations also accepted this rate with the report published in 1994. In developing countries, this rate reaches $13 \%$.

According to the 2007 population projections of Turkey's State Institute of Statistics, out of 74 million people, 2 million include infants and children between the ages of 0 and 10, and 12 million people aged 60 and over. The world's elderly population is very low in many countries, according to the average in Turkey in 2002, there are 8.5 million people with disabilities $12.29 \%$ rate according to total population [13]. According to the census results made in 2006 by the State Planning Organization in North Cyprus, the total population was announced as 256,644. 47,595 of the people are infants and children between the ages of $0-15 ; 27.429$ of them include individuals aged 60 and over [14]. Besides, there are records of around 5,900 individuals with various disabilities in the Labor Office in North Cyprus. Various users such as individuals with mobility restrictions, children, young people, the elderly, pregnant women, parents using strollers, disabled people use vehicles in the city. All of these users should be able to safely and comfortably use public transport in the city. Appropriate designs should be made for all users in pedestrian roads, vehicle roads and their surroundings, stops and stations, sidewalks, stairs and ramps, parking lots, urban equipment, and other uses in the city.

\subsection{Circulation in Public Buildings}

After the approach is provided to public buildings by vehicles or on foot, one of the essential criteria to be considered when designing public buildings is that the circulation within the building is suitable for everyone. A convenient access should be provided to everyone at the entrance door of the building. Access to the building entrance from the sidewalks and parking lots in the immediate vicinity should be convenient. If there is a level difference between the immediate surroundings and the building entrance doors, this problem should be solved by design suitable for everyone's use. It is essential to ensure circulation inside the building, starting with the building entrance doors' size to suit all types of users.

There are two directions of circulation within the building, namely horizontal and vertical circulation $[15$,
16]. While designing circulation elements in both directions, the diversity of individuals who will use the building should be considered. The circulation between floors is known as vertical circulation provided by building elements such as stairs, ramps, and elevators. For each floor to be suitable for everyone's use, care should be taken that there is no level difference within itself. If there is a level difference, this level should be exceeded so that it does not pose an obstacle for any user. It is essential that horizontal circulation elements such as corridors and halls are suitable for everyone's use and designed by considering the number of users. Also, taking into account different types of users, areas suitable for use by everyone should be arranged in the building's circulation. For example, for visually impaired users to access areas where they can operate, sensible surfaces should be designed, and horizontal circulation elements connections should be made carefully consider the maneuver areas of the wheelchair user. Thus, safe and comfortable horizontal circulation elements are created.

Riser heights when designing the stairs; it should be at a level that can be easily used by various types of users such as children, users with mobility difficulties, the elderly, pregnant women. Handrails on the stairs should be designed at different levels for different user heights. Besides, the width of the stairs should be determined by considering the number of users. The door and cabin dimensions of elevators should also be determined by paying attention to the number and variety of users. Ramps, which are the other essential elements of vertical circulation, their width and slope should be suitable and safe for different users such as wheelchair users and midwives using strollers. Also, all interior door widths, opening arms, and opening directions in horizontal and vertical circulation should be designed so that everyone can use it. When the horizontal and vertical circulation elements in the building are created, taking into account that the user mass of public buildings is everyone, the circulation is suitable for all users.

\subsection{Reaching Services in Public Buildings}

Providing access to the building and circulation within the building, giving everyone access to the services offered according to the building's function, and thus creating spaces that can meet the user's needs is also an essential criterion in the design of public buildings. There should be a set of guidance and warning equipment for easy access in buildings that will bring the user to the place he wants to go without any danger or negative situation and provide information. These are arrangements that can be understood with the senses of touch, sight, and hearing to serve individuals with various disabilities. These applications are especially important for visually and hearing-impaired users. For example, considering that visually impaired individuals are among the elevator users, 
audible warning systems should be installed in elevators. The buttons required for elevator use must be understandable by everyone and must have perceptible surfaces to suit visually impaired people. Also, elevator buttons should be positioned at a height for wheelchair users and other types of users, such as short-stacked users.

To provide information and guidance, information desks located close to the entrance doors or other desks for different purposes in the building should be designed for all users. The counters should be designed by considering the employee's types and actions who is the permanent user of the counter and other temporary users. Designing counters with sections of different sizes and features suitable for different users and various user activities will enable the counter right design for everyone's access. The presence of toilet groups within the building that other users can access and meet their needs can also provide access. Appropriate public buildings are designed with everyone's access to the building, horizontal and vertical movement within the building safely and comfortably, and access to all services within the building.

\subsection{Legislation Affecting the Universal Design Approach}

Approaching to building, circulation, and reaching to services must be considered to make designs suitable for everyone's use. There are some laws, regulations, standards, guidelines, and measures in all developed countries for achieving this. In the rules and declarations of many nations, all individuals in the society have equal rights. This equality should also manifest itself in spaces open to everyone. In this context, the American with Disabilities Act (ADA) was introduced in 1990 in America, where universal design emerged provides fundamental rights and the opportunity to participate in society [17]. The American Disability Law Standards (ADA Standards for Accessible Design) prepared in line with the ADA, which is the determinant of accessibility/accessibility standards; it aims to create regulations that will ensure the accessibility of disabled individuals to areas that are commonly used by the society [10]. The "Accessibility for the Disabled - A Design Manual for a Barrier-Free Environment" prepared by the United Nations also contains information that guides designers to create suitable environments and spaces for the disabled together with everyone [18]. The final version of which was adopted in Turkey, "Law on Disabled Persons" [19], is the law that assumes people with disabilities have the same rights as everyone else. According to this law; existing official buildings belonging to public institutions and organizations, all existing roads, sidewalks, pedestrian crossings, open and green areas, sports fields and similar social and cultural infrastructure areas, and all kinds of buildings that are open to the public and built by real and legal persons must be in proper condition. In order to achieve these, it is necessary to take into account the design rules of structural measures and markings for accessibility in urban roads, sidewalks and pedestrian crossings and TS 12576 [20], which were created by the Turkish Standards Institute, and the standards named TS 9111 [21] accessibility requirements in buildings for disabled people and people with limited mobility. In Northern Cyprus, on the other hand, there is the "Chapter 96: The law for arranging roads and buildings" [22] which was adopted in 1946 and is still valid, in which the rules regarding buildings and streets are determined. With the contributions of Chamber of Cyprus Turkish Architects, the article added in 2016 includes making the outdoor and indoor access standards suitable for the disabled. Considering the standards used by UN, Turkey and Chapter 96 that impact universal design, some regulations and measures that should be implemented in public spaces are compared in the tables below (Table 1 and Table 2). 
A Public Building in Northern Cyprus as a Case Study

Table 1. Some measures for outdoor arrangements

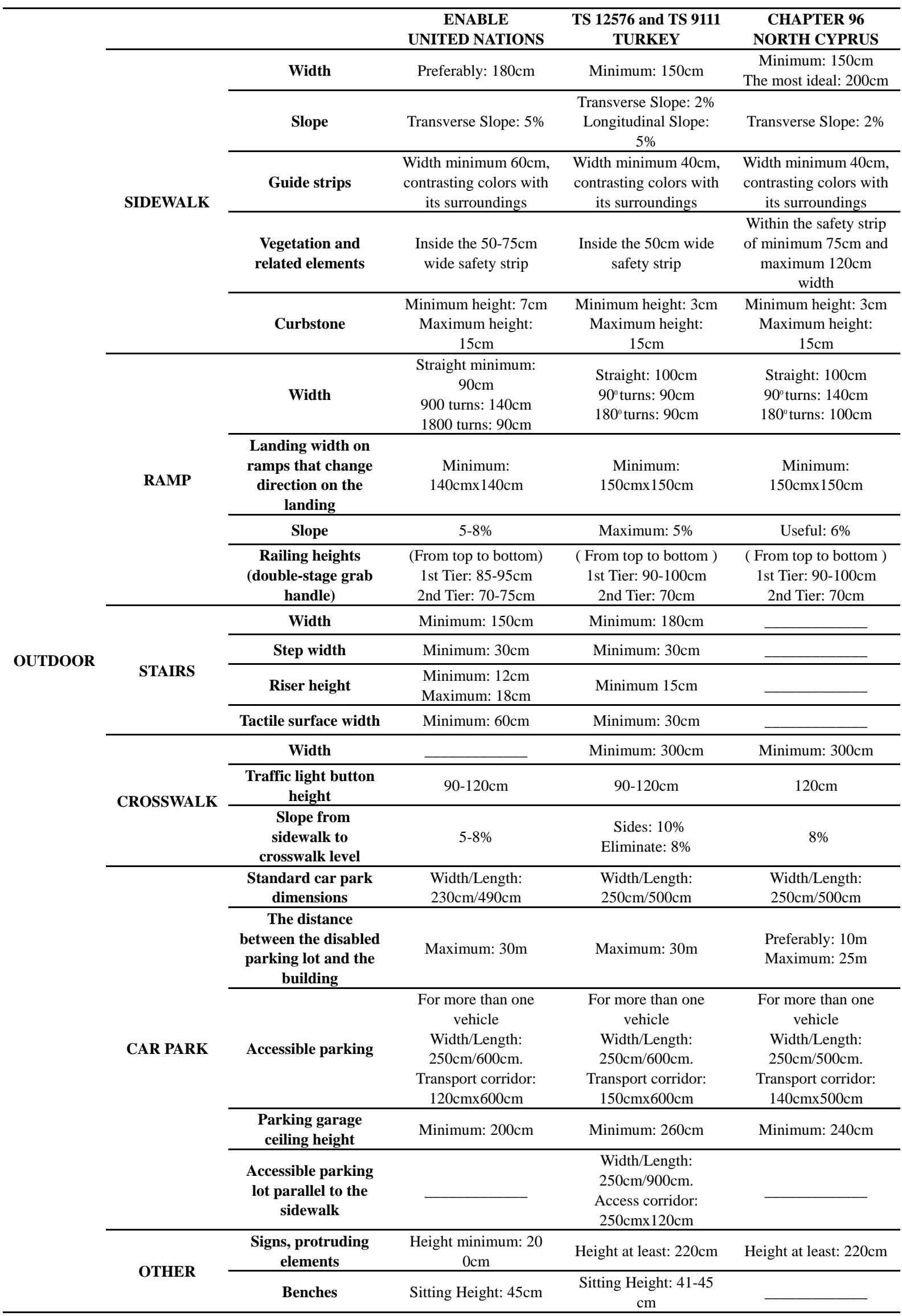


Table 2. Some measures for interior space regulations

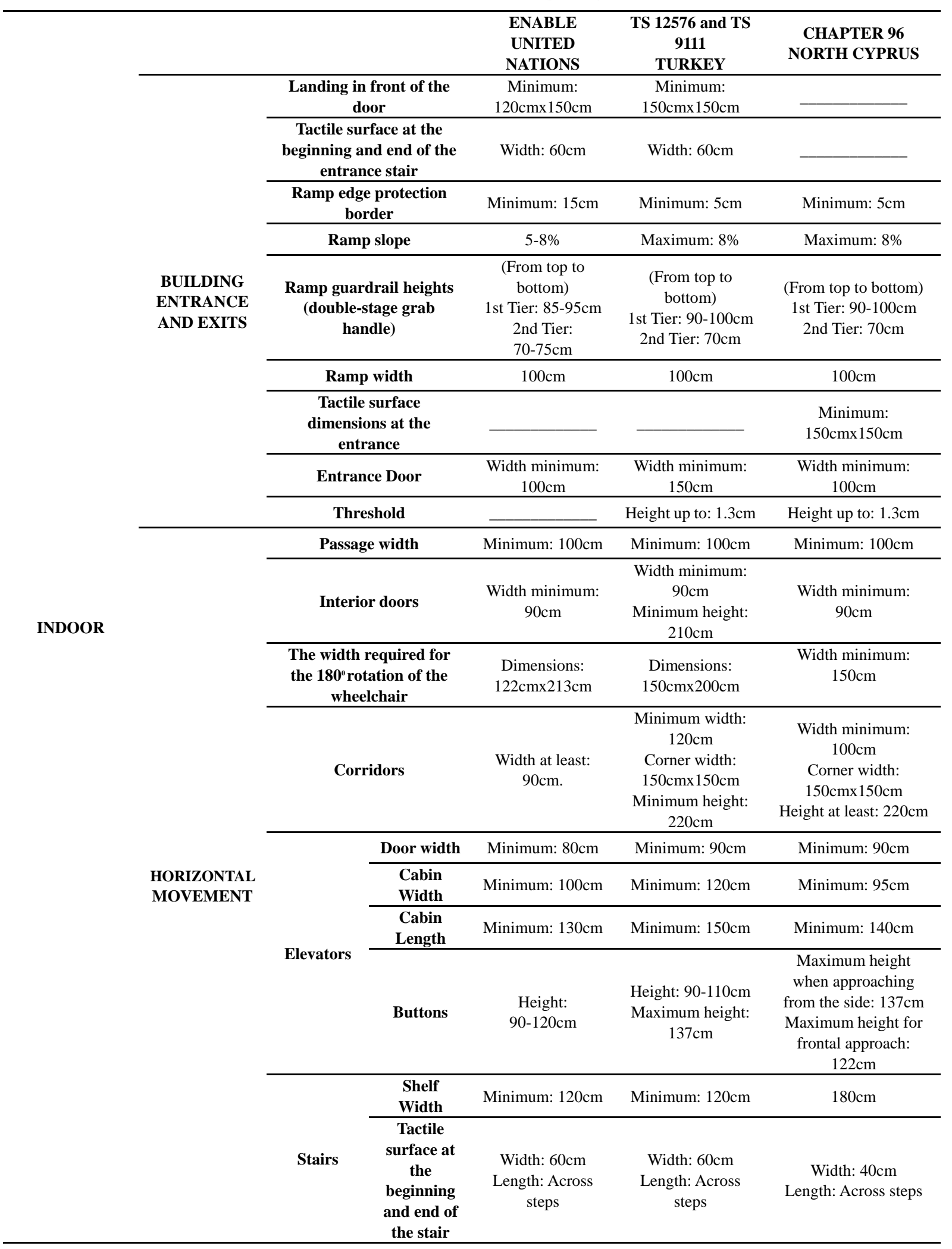




\section{Methodology}

This study aims to emphasize the importance of universal design in public buildings for the disabled and create a critical perspective to examine the compatibility of existing public structures with universal design principles. Following this purpose, by conducting a comprehensive literature research, the concept of universal design, its principles, the relevant legislation, the relationship between city and public structure has been examined, and information that can constitute a critical view has been obtained.

According to this information obtained from research, it is not considered correct to create a checklist to design a building suitable for universal design. But a systematic approach is needed to transform existing buildings into a form that everyone can use. It is seen that the framework of accessibility as approaching to building, circulation in building and reaching services in the spaces can be the main backbone of this systematic criteria approach. In this way, a systematic view by architectural planning scales will be supported and an infrastructure that provides appropriate data flow in transferring the needs of the public building user to the building system.

Wehrli's approach to transform the data of the "User System" into a "Building System" (Figure 1) overlaps with the criteria of "approaching to building", "circulation in building" and "reaching services in spaces". The data obtained for accessibility and circulation directly contribute to the data on physical and psycho-social user needs. Approaching to building is defined as the access of all individuals living in the city to all of the town's public services.

It is a definition that brings layout plan decisions to the fore in architectural design and questions the general transportation situation, the building's immediate surroundings, and parking lot arrangements. Circulation deals with building entrances and exits, including horizontal and vertical circulations within the building. Reaching services examines the spaces that make up the building parts; in other words, it questions each user action area's functional arrangement.

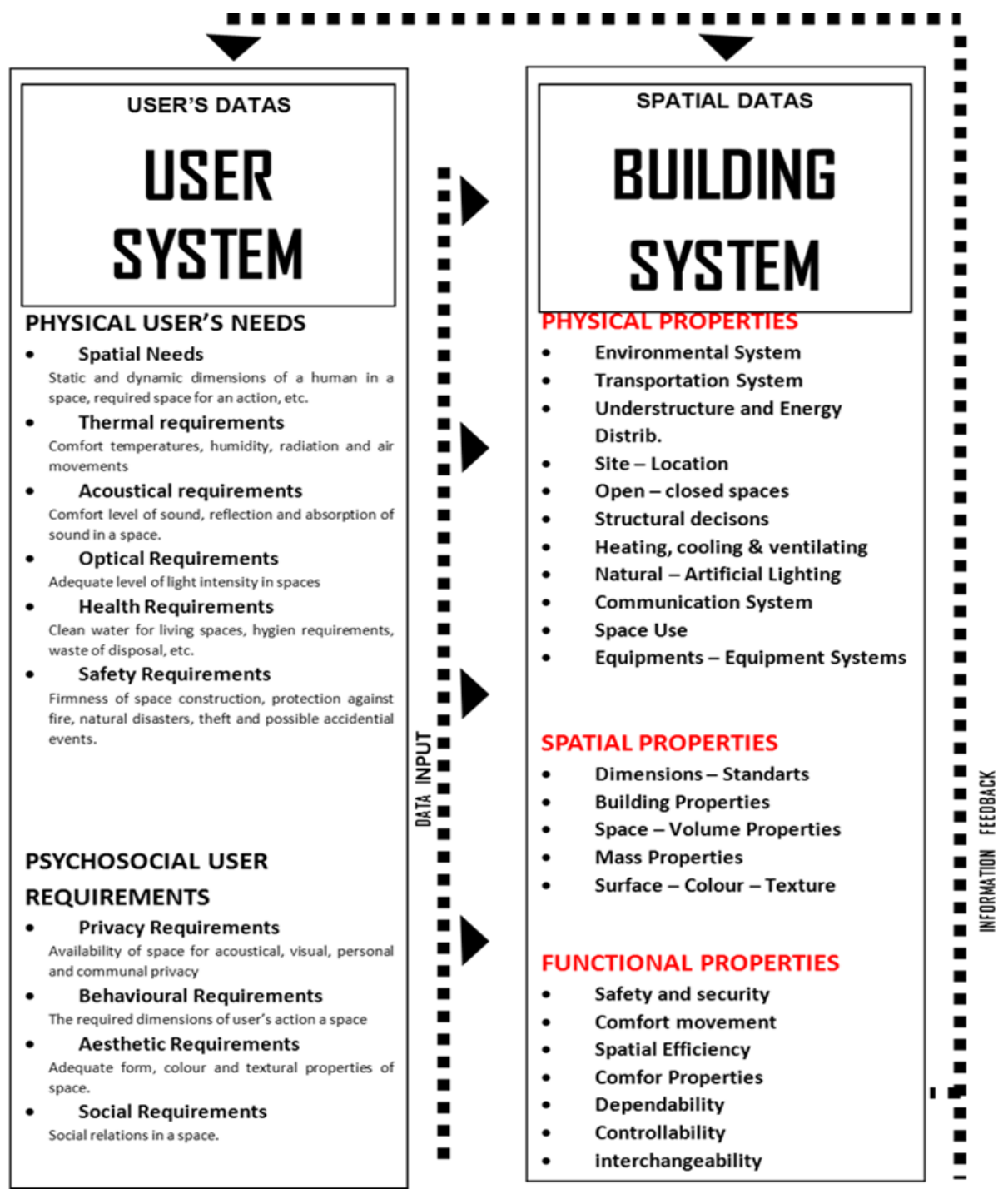

Figure 1. Wehrli's "NTIS" working scheme. The information received from the user system and transfers information to the building system [23] 
Table 3. Public building accessibility evaluation form

\begin{tabular}{|c|c|c|}
\hline & & Name of Public Building \\
\hline & Building Purpose & \\
\hline \multirow{3}{*}{$\begin{array}{l}\text { APPROACH TO } \\
\text { BUILDING }\end{array}$} & $\begin{array}{l}\text { Transportation } \\
\text { Status }\end{array}$ & $\begin{array}{l}\text { In which ways can access to the building be provided? } \\
\text { Are there any stops or drop-off points for public transportation vehicles located } \\
\text { near the building? }\end{array}$ \\
\hline & Near Environment & $\begin{array}{l}\text { - The roads, sidewalks, ramps, stairs in the immediate vicinity of the building are } \\
\text { positioned in appropriate places; Is it suitable for everyone? }\end{array}$ \\
\hline & Car parks & $\begin{array}{l}\text { - Do parking lots and pedestrian crossings meet the standards. Is it securely } \\
\text { regulated for everyone's use? }\end{array}$ \\
\hline \multirow{4}{*}{ CIRCULATION } & Building Entrances & $\begin{array}{l}\text { - How many entrances are there in the building? } \\
\text { - Are the entries detectable and usable by everyone? } \\
\text { Are the doors in the building suitable for everyone? What are the vertical } \\
\text { circulation elements in the building? }\end{array}$ \\
\hline & $\begin{array}{l}\text { Main Entrance } \\
\text { Door }\end{array}$ & Is the main entrance door perceptible and usable by everyone? \\
\hline & $\begin{array}{l}\text { Horizontal } \\
\text { Circulation }\end{array}$ & Are corridors and halls suitable for use by everyone for horizontal circulation? \\
\hline & Vertical Circulation & Are vertical circulation elements suitable for different user groups? \\
\hline \multirow{3}{*}{$\begin{array}{l}\text { REACHING TO } \\
\text { SERVICES }\end{array}$} & $\begin{array}{c}\text { Information Desk } \\
\text { and Other counters }\end{array}$ & Are the counter heights suitable for different user sizes to reach? \\
\hline & Waiting Area & $\begin{array}{l}\text { - Do the waiting areas allow different users to wait together under the same } \\
\text { conditions? }\end{array}$ \\
\hline & Wet Spaces & $\begin{array}{l}\text { Do toilet groups offer options for users with different characteristics (such as tall, } \\
\text { short, children, elderly, wheelchair users)? }\end{array}$ \\
\hline
\end{tabular}

In summary, the concepts of "approaching to building", "circulation in building" and "reaching services in spaces" correspond to site plan (layout) decisions, space and section arrangement decisions, and action area arrangement decisions, which are the design scales in architecture (Figure 2).

\begin{tabular}{ccc}
\hline DESIGN SCALE & $\begin{array}{c}\text { PUBLIC BUILDING DESIGN } \\
\text { EVALUATION CRITERIA }\end{array}$ \\
\hline $\begin{array}{c}\text { BUILDING LAYOUT DECISIONS } \\
\text { ARILDING SECTION AND SPACE } \\
\text { ARRANGMENT DECISIONS }\end{array}$ & APPROACH TO BUILDING \\
\hline $\begin{array}{c}\text { ACTIVITIES AREA REGULATORY } \\
\text { DECISIONS }\end{array}$ & CIRCULATION \\
\hline
\end{tabular}

Figure 2. Relationship between design scale and public building design evaluation criteria

In the framework of the issues mentioned above, the conformity of a public building in Northern Cyprus and its immediate surroundings, selected as the study area. The building has been examined with the evaluation form set up in Table 3 with the universal design criteria.

The study examined accessibility, transportation, immediate surroundings, parking lots, circulation, building entrances, main entrance doors, horizontal and vertical circulation elements, information desk and other counters, waiting areas, and wet places.

\section{Case Study}

\subsection{Location and Features of the Study Area}

The investigated building is in the northern part of Cyprus, in the capital Nicosia and is located in the same area as many public buildings used by the state administration (Figure 3). Built in 1998; It has a total of six floors, including the basement and ground floor.

The office building has a usage area of approximately $9220 \mathrm{~m}^{2}$. It is a building used by the whole community, as it provides services to the public in various units. Many users use this public building and its immediate surroundings, so it was chosen as a study area to be examined from a universal design perspective.

The building is located close to Bedrettin Demirel Caddesi, one of the city's essential streets. The road on the street with heavy vehicle traffic; is designed to have two departures and two arrival lanes separated by a median. There are lighting poles in the median that continues along the street. There are sidewalks on both sides of the road designed for pedestrians. There are traffic signs on the sidewalks where necessary. On the double lane on Bedrettin Demirel street, there are stops for public transportation on both routes. Individuals coming to this building by public transport should walk to the building after getting off at the stops mentioned above. A pedestrian crossing has been designed on the street with heavy traffic. This pedestrian crossing is located close to the bus stops on the road's lanes. After getting off at the stops, there is no sidewalk along the way to reach the inspected public building. Pavements are divided by vehicle roads and are higher than the vehicle road level. Users can also access the building with their private vehicles. An open car park was planned on the building's front and rear facades for the users who access the building with their cars. There are four accessible parking areas within the parking lot located close to the building on the front façade. 


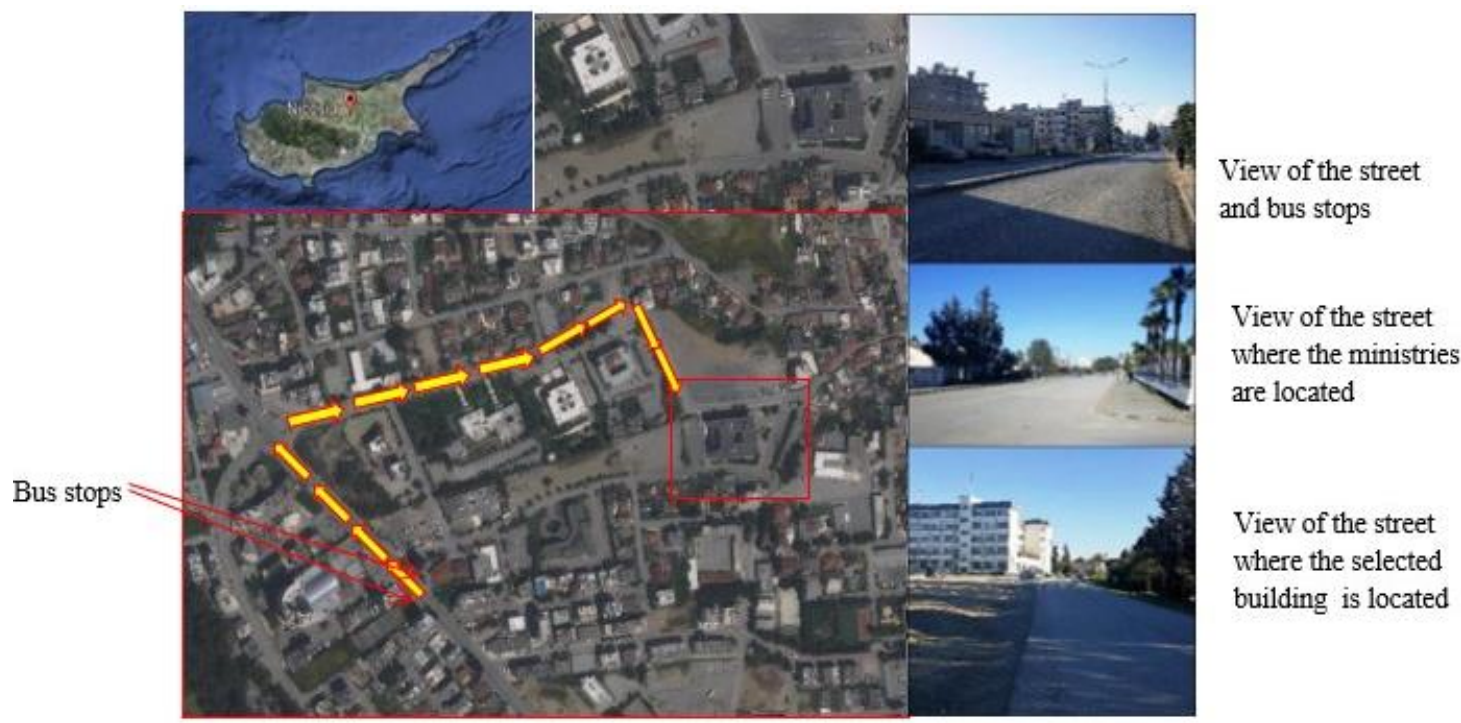

Figure 3. The walking route from the stops to the public building and the roads on the route [24]

Employees and other users, who are permanent users of the building, prefer to reach the building with their private vehicles. For this reason, the open car parks arranged are insufficient. The parking lot need is met using the empty lands on the right side and rear facades of the building. After accessing the building, users can use seven existing entrance gates for entering the building. Two of the doors are service entrance doors located on the basement floor and accessed by ramp descent. One of the remaining five entries is the entrance to the stairs from which the minister can directly access his office.

The other four doors, one of which is the main entrance door, are open to everyone. The levels of all entrance doors are higher than the outdoor pavement level. A ramp was used to enter the service doors on the basement floor. The access to one of the five entrance doors on the ground floor was by a ramp, and steps were designed for the other users. The main entrance door of the building was emphasized by a porte-cochere. This door opens onto a wide entrance hall. There is a spiral staircase and two elevators connecting the floors. The stairs and elevators here do not serve the basement floor. The entrance door with a ramp on the right side of the building is connected to the main entrance hall through a short corridor.
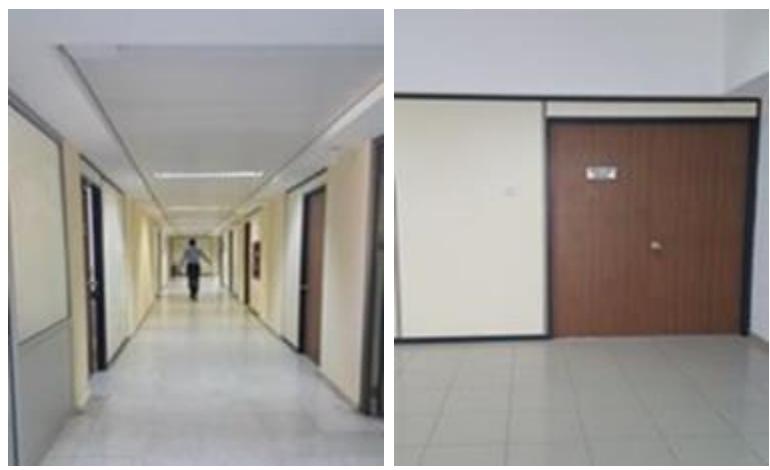

Figure 4. Corridors, halls, entrance doors (Author, 2016)
There are halls and corridors to ensure horizontal circulation within the building. There are double-wing, aluminum-framed glass doors in some places between the hallways and corridors with a width of $220 \mathrm{~cm}$. Room entrance doors are usually $100 \mathrm{~cm}$ wide, single-wing, wooden doors. The rooms' entrance doors, such as meeting rooms, are designed as $180 \mathrm{~cm}$ wide, double-winged wooden doors (Figure 4). There are signs with short texts on the room doors to indicate the purpose of use of the room.

There are counters in different places in the building for information and transaction. The small information and security counter in the entrance hall is made of wood. The counter, which is approximately $90 \mathrm{~cm}$ in height, is fixed at an appropriate level so that the employee can write while sitting. The main information room and waiting area are positioned in the hall with aluminum glazed doors and panels between the entrance hall. The wooden information desk has a height of approximately $1 \mathrm{~m}$ and a glass about $80 \mathrm{~cm}$ on top (Figure 5).

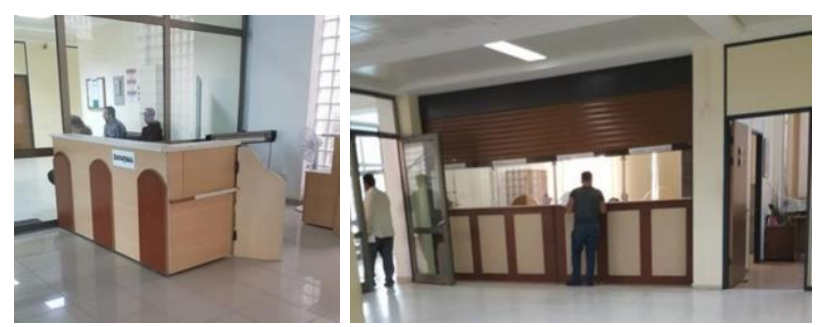

Figure 5. Small information desk at the entrance and the main information desk (Author, 2016)

In the building, there are different types of counters in many units such as the Immigration Office and the Civil Registry Office (Figure 6). All of these desks have benches suitable for the employee to write while sitting. 

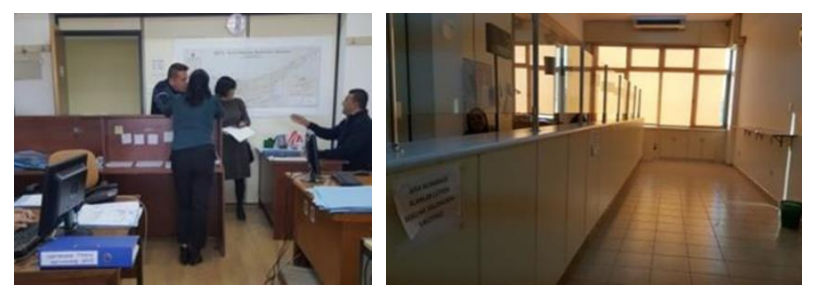

Figure 6. Different counter types in the building (Author, 2016)

On all building floors where the public is served in different units, waiting areas are arranged in many places. Waiting areas were positioned as a separate room by placing seating furniture in the halls or corridors; in some places separated by benches in the work area (Figure 7).
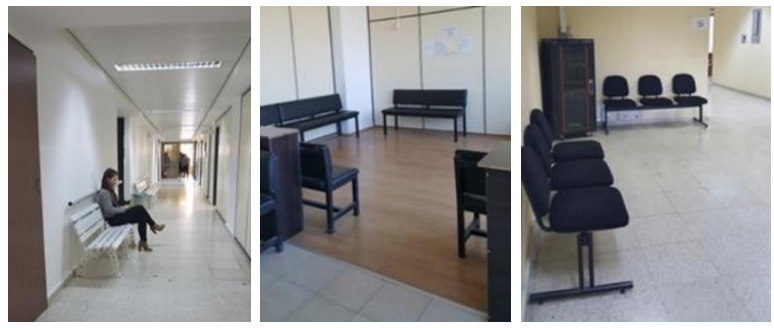

Figure 7. Waiting areas of the building (Author, 2016)

There are many office-function rooms on the floors. There are offices used by one person and offices where a room is organized for the shared use of more than one employee. Offices also have seating furniture that can provide waiting. Due to the high number of users in some offices, office circulation space becomes not sufficient (Figure 8).

It was seen that on each floor, male, female, and accessible toilets were positioned as a group to receive air and natural light from the courtyard in the middle of the building (Figure 9). The bathrooms arranged for the disabled are for one-person use. There is one sink and toilet inside. Grab handles are designed next to the closet. The mirror is positioned inclined so that a sitting individual can see himself.
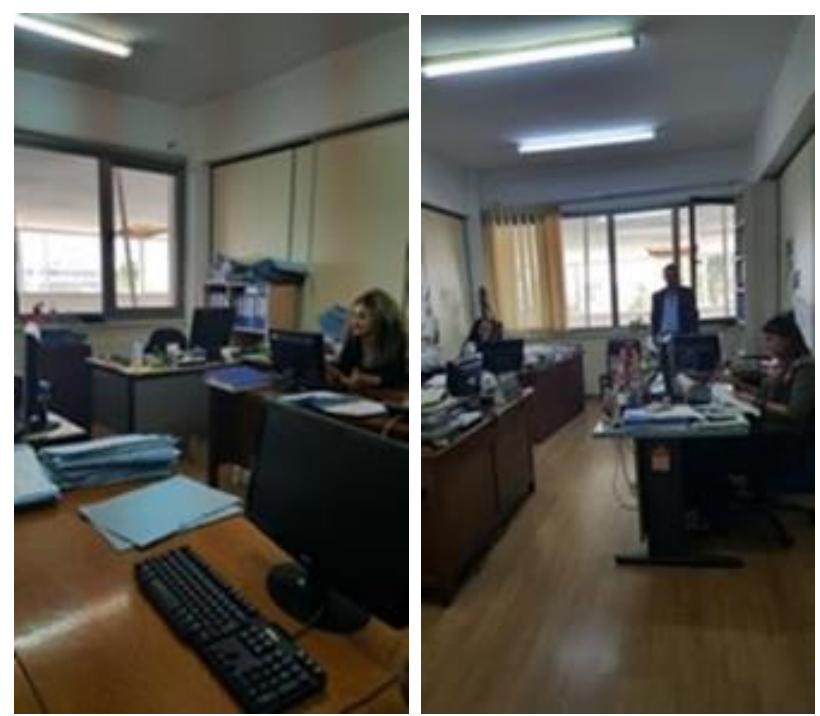

Figure 8. Offices in the building (Author, 2016)

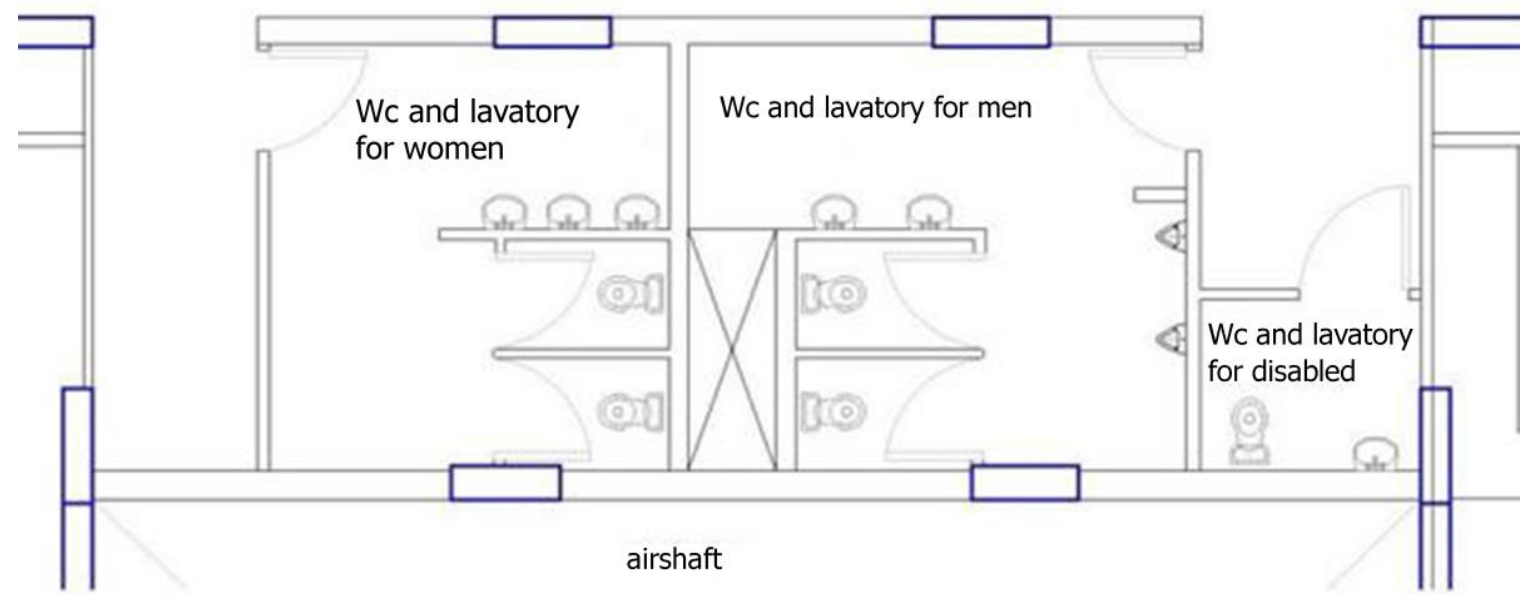

Figure 9. Current status of toilet groups (Author, 2016) 
There are three cafeterias in the building. The ones located in the interior have met their ventilation and natural light requirements through the $1246 \times 1208 \mathrm{~cm}$ wide courtyard designed in the middle of the building. In the space reserved for cafeterias, it was possible to arrange a small number of seating areas. One of the cafeterias is on the ground floor and has a door to the courtyard area. (Figure 10). By the connection established with this door, the courtyard is arranged as an outdoor seating area. In the cafeterias, there are counters arranged for selling and preparing products

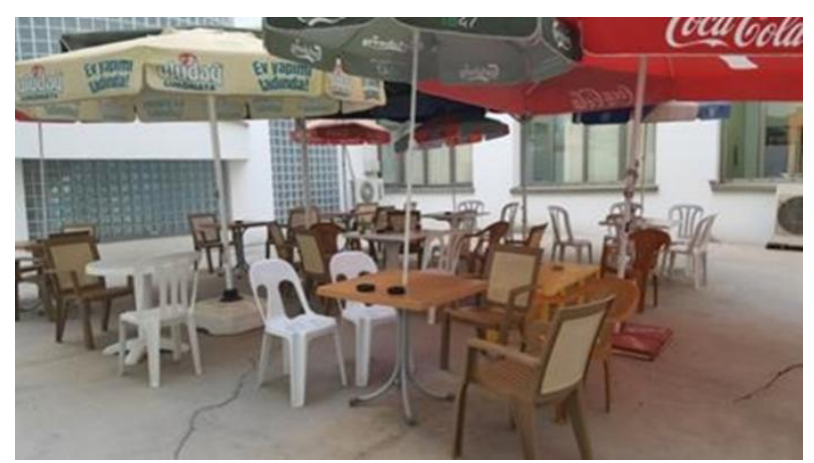

Figure 10. Cafeterias inside the building (Author, 2016)

In the building built with a reinforced concrete system, brick, solid panel, and half-glazed blinds panel materials are used to divide walls that make up the spaces. The building's current situation, which is open to the public, was examined together with its immediate surroundings.

Findings were obtained as a result of the examination of the public building and its nearby environment; the current situation of the building and its immediate surroundings under the main headings of accessibility, circulation and access are summarized in Table 4.

\section{Results and Recommendations}

Universal design aims to make designs that allow the common use of many types of users. It is a concept that seeks to create designs suitable for the benefit of all individuals of all ages, regardless of language, religion, gender, physical or mental characteristics. The concept of universal design, which is thought to be taken into account in the design of public buildings that are open to everyone, has no rules or standards.
Approach to the building can be provided by public transport or private vehicles. Users who prefer to reach the building by public transport should walk to the building after getting off on Bedrettin Demirel Street, where the closest public transport bus stops are located. Those who get off at the bus stop on the west side of the road on this street, designed by dividing the double lane road with the median, must cross. There is a pedestrian crossing to allow passage to the opposite sidewalk. However, the designed pedestrian crossing does not have suitable conditions for safe crossing by everyone. A wheelchair user, a person walking with a stroller, should be able to descend from a sidewalk to the road level by a ramp and climb to the opposite sidewalk in the same way. This arrangement is not sufficient for the pedestrian crossing on Bedrettin Demirel Street. On the road with a refuge in the middle, it should be possible to climb and descend on the refuge with a ramp. The part of the refuge that corresponds to the pedestrian crossing should be lowered to the level of the pedestrian crossing. Besides, sensible surfaces should be placed at the beginning and end of the pedestrian crossing and inside the refuge so that visually impaired individuals can perceive it.

It is shown in Figure 5 that there is no pavement on the entire route where individuals arriving by public transport will walk to the building after getting off at the stops, and the pavements found are divided by vehicle roads in places. The current state of the pavements is not suitable for everyone.

Accordingly, it is recommended to design pavements in areas where there are no pavements, review the existing pavements in the region, and arrange the design of all of them following the universal design principles.

The width of the sidewalk should allow two wheelchair users to pass side by side. The arrangement of a perceptible light-colored floor along the sidewalk for the visually impaired should be provided. In this way, pavements suitable for everyone's use can be arranged, and the principles of equal use and perceivable information of universal design are taken into account. When examining the building's parking spaces, which are arranged on the front and rear facades of the building for users who will access the building with their private vehicles, there are four accessible parking spaces the current parking area. However, the regulations to be applied for accessible parking spaces are not applicable for these areas. 
Table 4. Findings obtained as a result of the examination of the selected public building

\begin{tabular}{|c|c|c|}
\hline & & The Selected Public Building \\
\hline & Building Purpose & Office building \\
\hline \multirow{3}{*}{$\begin{array}{l}\text { APPROACH TO } \\
\text { BUILDING }\end{array}$} & $\begin{array}{l}\text { Transportation } \\
\text { Status }\end{array}$ & $\begin{array}{l}\text { After getting off at the stops in the region by public transportation, you can reach the } \\
\text { building on foot or by private vehicles. }\end{array}$ \\
\hline & Near Environment & $\begin{array}{l}\text { The sidewalks, ramps, pedestrian crossings on the route to walk to the building after } \\
\text { getting off at the stops are insufficient and they are not designed for everyone's use. }\end{array}$ \\
\hline & Car parks & $\begin{array}{l}\text { Open car parks are planned at the front and rear of the building. However, since } \\
\text { transportation to the building is mostly provided by private vehicles, these parking lots } \\
\text { were insufficient. For this reason, users park their vehicles in the empty lands on the right } \\
\text { side and rear facades of the building. }\end{array}$ \\
\hline \multirow{4}{*}{ CIRCULATION } & Building Entrances & $\begin{array}{l}\text { Two of the seven entrances are service entrances in the basement. One of the remaining } \\
\text { five gates is intended for direct entrance to the minister's office, and the other four } \\
\text { entrances, one of which is the main entrance door, are open to everyone. However, the } \\
\text { level difference between the entrance doors and the building floor was overcome with a } \\
\text { ramp for only one entrance door, and only stairs were used to overcome this difference in } \\
\text { others. }\end{array}$ \\
\hline & $\begin{array}{l}\text { Main Entrance } \\
\text { Door }\end{array}$ & $\begin{array}{l}\text { The main entrance door, which is highlighted by the overhangs, is designed to be an } \\
\text { automatic sliding door that opens to both sides after passing through the double-wing } \\
\text { aluminum cased glass door. Door widths are suitable for everyone. }\end{array}$ \\
\hline & $\begin{array}{l}\text { Horizontal } \\
\text { Circulation }\end{array}$ & $\begin{array}{l}\text { Doors were placed in necessary places between the designed corridors and halls. The } \\
\text { width of these doors is suitable for everyone. Room entrances are generally provided } \\
\text { with single wing doors. The entrance doors of the rooms such as the meeting room are } \\
\text { designed wider. }\end{array}$ \\
\hline & Vertical Circulation & $\begin{array}{l}\text { There is a staircase and two elevators in the hall where the main entrance door is opened. } \\
\text { In addition, stairs are designed right next to the entrance doors from the right and left side } \\
\text { facades. The circulation between floors is provided by three stairs and two elevators. }\end{array}$ \\
\hline \multirow{3}{*}{$\begin{array}{l}\text { REACHING TO } \\
\text { SERVICES }\end{array}$} & $\begin{array}{c}\text { Information Desk } \\
\text { and Other Counters }\end{array}$ & $\begin{array}{l}\text { The heights of all the benches are designed in accordance with the size of a standing } \\
\text { human. Different features are not considered for different users in the counters. }\end{array}$ \\
\hline & Waiting Area & $\begin{array}{l}\text { Waiting areas are arranged in many places on all floors. Although these areas are } \\
\text { sometimes designed as waiting rooms, sometimes they are also provided with sitting } \\
\text { furniture in the halls or corridors. }\end{array}$ \\
\hline & Wet Spaces & Male, female and disabled toilets on each floor are positioned as a group. \\
\hline
\end{tabular}

For wheelchair users with special needs to get out of the vehicle, a circulation corridor with a width of wheelchairs between two cars was not available. And the parking space was not colored with the disabled symbol perceived by everyone. The sign with the text stating that there is an accessible parking area is attached to the building wall in front of the parking lot. Besides, a sign with the disabled symbol, which everyone perceives, is fixed on the building wall for information (Figure 11).
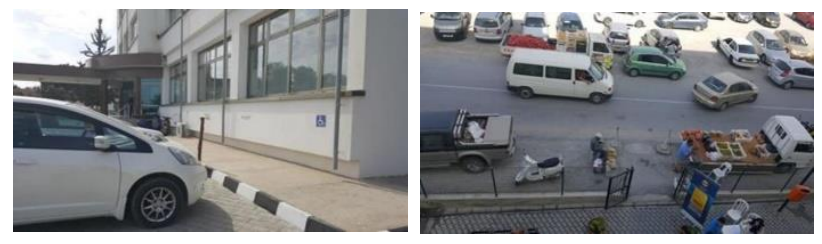

Figure 11. The existing accessible parking areas and the existing vacant area used as parking lot (Author, 2016)

Since the users mostly come to the building with their private vehicles, the designed parking areas were insufficient, and the empty lands around the building started to be used as parking areas. There are no routing for vehicle entrances and exits in these areas. Individuals park their vehicles on the empty land irregularly because there is no parking arrangement on the ground. It has been observed that these areas, which do not have vehicle entry-exit guidance or parking area arrangement, are dangerous for users. If the areas continue to be used as parking lots, it is recommended to design a parking lot suitable for everyone.

According to Istanbul parking regulations, it is mandatory to have at least one parking lot with a disabled sign for every twenty vehicles in the parking lot. This requirement has been taken into account in the proposed parking plan. Parking areas reserved for the disabled are located close to the single ramp entrance in the building. Sidewalks, ramps, and pedestrian crossings have been proposed to access the building from the car park.

By the proposed sidewalks and ramps, the entrances from the empty land used as a parking lot to the land where the building is surrounded by fences and where the entrance gates are arranged become suitable for everyone's use. In the current situation, the parking area reserved for the disabled is located close to the building's main entrance. However, because the building entrance height is not at the same level as the pavement or parking lot and stairs overcome this level difference to access the main entrance door, wheelchair users cannot use the main entrance door to enter the building. Of the five entrance doors on the ground floor currently; the only entrance door that wheelchair users or strollers can enter is the door on the right side of the building, where a ramp overcomes 
the difference in level between the pavement and the entrance door.

A stair was used to overcome the difference in level in other entries. This situation causes the disabled to use the ramp door to enter the building. Without a special design for the disabled, by making standard designs that everyone can use, there has not been a universal design that aims to make the disabled a part of society without separating them from the community. It is recommended to design a ramp suitable for everyone's use instead of stairs to access the main entrance. In this way, the principles of flexible use and low physical power use of universal design are considered.

The main entrance door consists of two rows of doors. In the first row, a $200 \mathrm{~cm}$ wide double-winged door opens inwards; then, there is a $200 \mathrm{~cm}$ wide sliding door with sensors. Other ground floor entrance doors are $180 \mathrm{~cm}$ wide double-winged doors.

It is recommended that at least two of the entrance doors have sensors, sliding to both sides and controllable to be opened and closed from the information desk when necessary. It is recommended that the remaining double-wing doors open in the direction of escape, to the outside, in case of emergency. If the recommendations are followed, the arrangement is made following the low physical strength principle. The main entrance door of the building, highlighted by the eaves, is an example of the simple and intuitive use principle of universal design.

In the entrance hall, where the main entrance door is opened, there is a spiral staircase for vertical circulation, and two elevators positioned side by side. The elevators here are the only elevator groups in the building. User types such as users with walking difficulties, wheelchair users, parents using strollers must use the elevator group in this hall for circulation between floors. All entrance doors that provide access to the building do not open to the main entrance hall. It is recommended to design an elevator group in a different area that can be easily accessed by individuals who use other entrances and use elevators in vertical circulation inside the building. Thus, according to the flexible usage principle of the universal design, the user is allowed to make different choices by offering options.

The halls and corridors in the building are suitable for horizontal circulation. Room doors are generally $100 \mathrm{~cm}$ wide. The entrance door of the rooms, such as the meeting room, is designed as $180 \mathrm{~cm}$. Door widths are suitable for many types of users (Figure 12). The movement of a visually impaired individual in these rooms can be difficult and dangerous. Besides, there are no wide circulation areas that allow wheelchair users to move around.

Visually impaired people are generally not taken into consideration in building design. For the visually impaired to proceed safely, noticeable surfaces are not arranged on the circulation areas' floors. Also, there is generally no audio information system in the building. It is recommended for the visually impaired to lay sensible floors on necessary places such as elevator entrances, stair starts, and ends [25].

Tactile surfaces can be used for safe circulation horizontal and vertical in the building, reaching the information desk from the building entrances. There are counters in many places in the building for information or transaction processing. These benches' height is suitable for standing adult men, adult women, and ten years old boys (Figure 13). However, an individual who is a wheelchair user cannot approach the desks at the present height and cannot communicate and operate with the employee sitting behind the counter face-to-face.
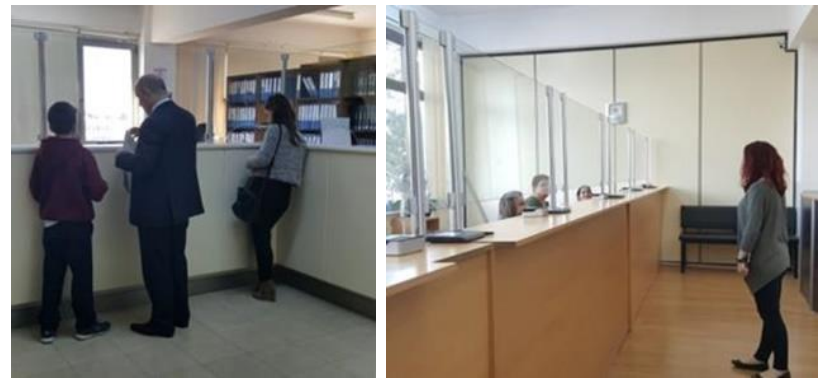

Figure 13. Available counters suitable for standing adult men, adult women and 10 years old boys (Author, 2016)

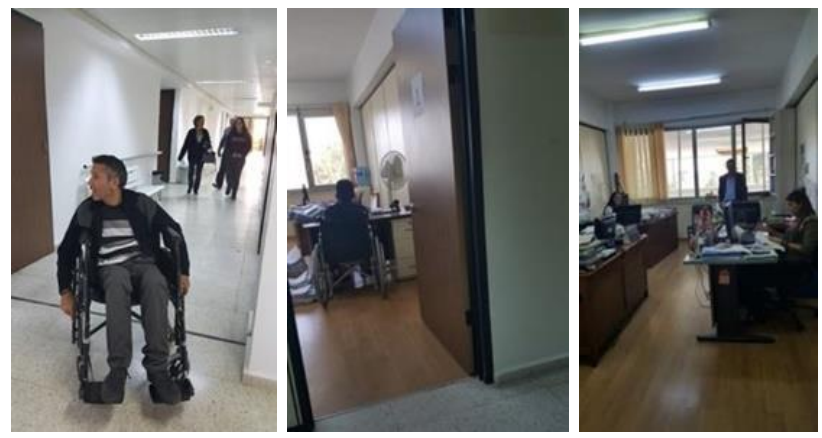

Figure 12. Circulation of the users in the halls and corridors, sufficient width of the room entrance doors, restriction in the room due to the large number of users (Author, 2016)

The existing banks are not suitable for everyone. Designing desks with varying heights ideal for everyone's use is recommended. The technical drawing of the counter-proposal is shown in Figure 14. The waiting areas arranged in many places within the building had been shown previously in Figure 7. The seating furniture in the waiting areas are generally the same type of furniture. Individuals with different physical characteristics will use these waiting areas. It is recommended to position seating furniture with various features in the same place. In this way, the users are offered different choices, and the principle makes a design of flexibility in the use of universal design. There are spaces in the existing waiting areas in the building for wheelchair users to wait in places where they can adapt to the seating arrangement. Besides, 
these spaces are suitable for people who are in the waiting area with a stroller. There are three cafeterias on different floors within the building. The cafeterias' preparation and sales counters have heights enough for the employee and the customer to communicate. However, a wheelchair user cannot come close to the existing bench. It is recommended that these areas should be arranged for different users. Space reserved for cafeterias, since the seating arrangement is not wide enough, is possible to sit with a small number of tables and chairs. It is possible to include wheelchair users or parents with strollers in the existing layout. There is an exit door from the cafeteria to the courtyard on the ground floor. By this connection, an outdoor seating area was arranged in the yard. The seating area, which is set without leaving enough space for circulation, is open to everyone. It is recommended to place different types of tables and chairs in the area where the same kind of tables and chairs are used, provide options to the user, and allow everyone to move by leaving circulation areas in the seating arrangement.

There are toilet groups for men, women and accessible toilets on each floor within the building. In the area where the sinks are positioned at the entrance, toilet cabinets and urinals are separated from the washbasins. For the users with different physical characteristics, fittings at different heights should be used (Figure 15). The sink fountains in the space have rotating arms. The use of hand sensor fountains, is recommended for saving water and being a design that complies with the low physical power principle of the universal design.

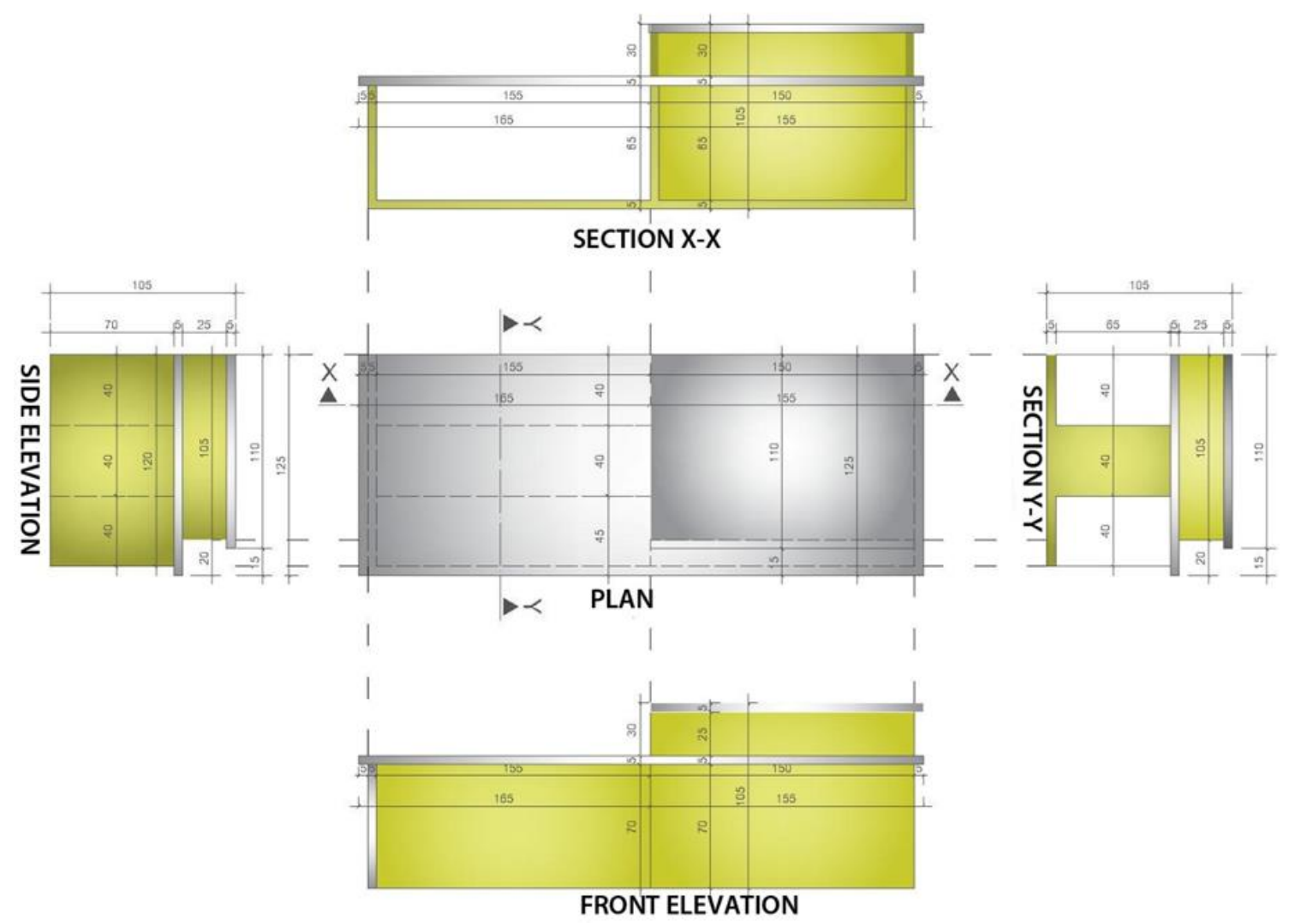

Figure 14. Technical drawing of the counter proposal (dimensions are in centimeters) (Author, 2016) 

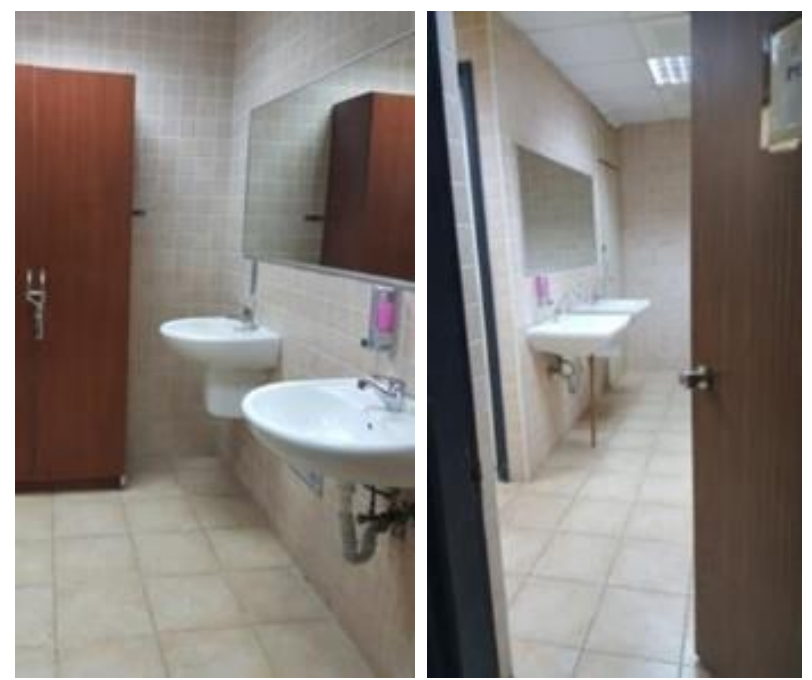

Figure 15. Washbasins in ladies' and men's toilets fixed at the same height (Author, 2016)

Here, it is seen that the design is made following the principle of providing size and space for the approach and use of universal design. Also, handling at the toilet sides was designed in the accessible toilet, allowing a wheelchair user to meet their needs without assistance (Figure 16). The washbasin here is also designed for the wheelchair user to approach. It is recommended to use a hand sensor fountain in the washbasin with a fountain model that opens and closes in one move. The door in the accessible toilet section of the toilet groups opens to the outside to facilitate access for wheelchair users.
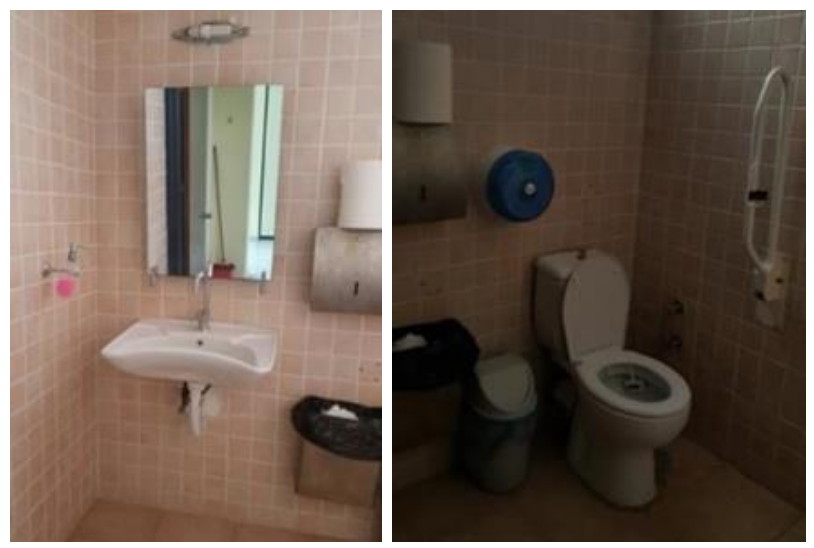

Figure 16. Disabled toilet facilities (Author, 2016)

There are informative texts on the room's function or by whom it is used on all room doors in the building. However, considering different types of users such as illiterate users and visually impaired persons, it is recommended to have systems in the building where information can be obtained using the same understandable symbols and symbols through sound, touch, or when seen. When the characteristics of the building and its immediate surroundings are considered in general, it is seen that some designs have been made assuming that transportation, circulation, and access are suitable for different users. Still, it is thought that the building used by the public and its immediate surroundings will be more ideal for all users if the regulations in the proposed suggestions are made.

\section{Conclusions}

The aim was to examine and evaluate today's public buildings based on accessibility, circulation, and access design criteria. Legislations affecting the universal design approach have been reviewed. In this framework, the "user system" was transformed into a "building system," and an evaluation table was obtained based on criteria.

A public building and its immediate surroundings in northern Cyprus have been examined and evaluated from a universal design perspective. Recommendations have been developed (Figure 17). The workspace has been assessed from a universal design perspective, and suggestions, including architectural arrangements, have been made to make it suitable for various user groups. According to the investigations made in the study area in Nicosia, it was seen that the public transportation, the sidewalks, pedestrian crossings, which are the elements of urban pedestrian circulation, should be improved with a universal design perspective. Providing convenient access to the building by public transport or private vehicles is vital.

Ensuring easy circulation and access within the building for all users is also very important. Although the corridors and halls, which are the main horizontal circulation elements in the building, have sufficient space for everyone to move around, it has been determined that the circulation areas inside the rooms are insufficient, as many rooms used as offices by more than the user capacity. Although vertical circulation elements are suitable for everyone's use, the elevator group at one point was deemed insufficient for the building, and another elevator group was proposed at another point. In this way, the user was given a choice. In general, writings about the room's function or user are available on the doors for information in the building. However, informing only in writing does not allow everyone to get enough information. Considering the visually impaired or illiterate users, it has been suggested to give information with audible warning systems or symbols that everyone perceives. When looking at the building in terms of access, it was seen that the furniture used was not suitable for all individuals. For this reason, it has been suggested to design furniture ideal for everyone's use. It is necessary to interpret the architectural programs with a contemporary understanding and design spaces suitable for universal design in the entire building and its immediate surroundings. As a result of the researches and examinations, it was emphasized that it should be taken into consideration that the user is everyone in the society while designing public buildings in general. 


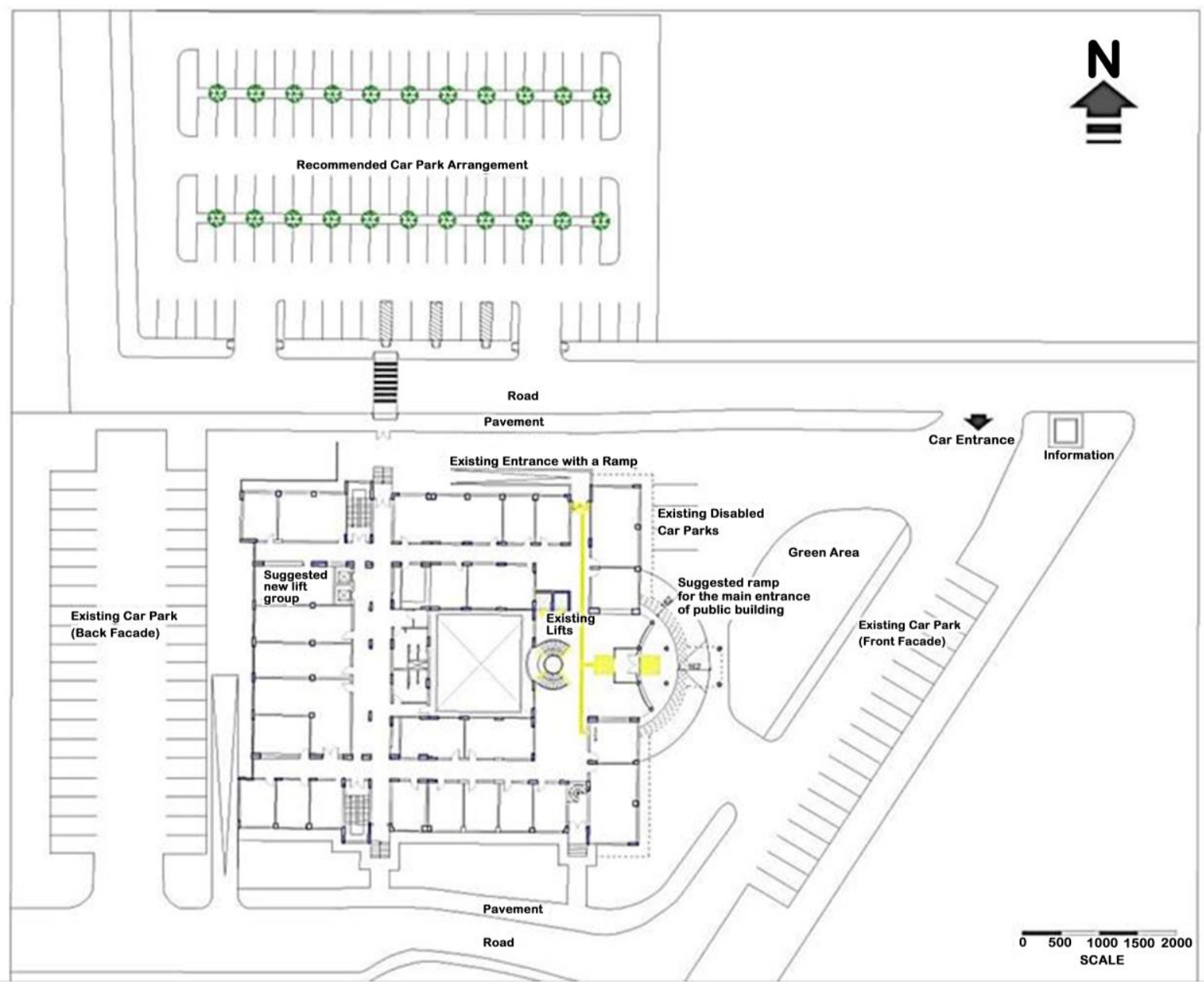

Figure 17. The proposal for the selected public building - recommendations on the basis of universal design (Author, 2016)

Besides, one should be aware that everyone in society has different visual, auditory, and mental characteristics. It should not be forgotten that users who have physical or mental disabilities in a period of their life or their entire life also use public buildings. In addition to all these, while designing with the awareness that the user base of universal design is everyone in society, arrangements should be made that everyone can use regardless of their ability and proficiency level such as language, religion, race, gender, age, illiteracy. Along with the public buildings, the cities in which they are located must have qualifications suitable for everyone's use. Public transportation and bus stops, sidewalks, pedestrian crossings, urban furniture and equipment, stairs, and ramps in the city should be suitable for everyone. When the city of Nicosia is examined from the perspective of universal design in general, it is seen that the transportation means offered to the public in the city are not suitable for everyone. There is no public transportation ideal for the comfortable use of a wheelchair user, a person moving with a stroller, or a visually impaired individual. As a result of the research, it was learned that disabled people generally use their private vehicles for urban circulation or that this user group provided by the Orthopedic Disabled Association and Nicosia Turkish Municipality can provide transportation with appropriate vehicles. Disabled people must also make an appointment to use these tools of the relevant institutions. Instead of including the disabled in society, special solutions are considered for the disabled users by providing transportation opportunities independent from the community. Bus stops, sidewalks, and pedestrian crossings generally found in the city, are also not suitable for everyone. According to these determinations, it can be said that there is a need for an organization that will make the necessary arrangements for the units of the state, which are primarily responsible for ensuring urban circulation by vehicle and on foot. The awareness of the presence of disabled people in society has not been widespread enough in Northern Cyprus. In Chapter 96, the law on the regulation of roads and buildings, the requirements for the design of streets and buildings suitable for the use of the disabled are regulated under Article 19 and published in the official gazette on 29 November 2016 (Chapter 96, 2016). To reflect this positive development to life, it should be ensured that the necessary control mechanisms are useful in both project and construction stages. With Nicosia Turkish 
Municipality and some non-governmental organizations, an increasing number of the projects that encourage regulations for the disabled and hygiene in workplaces will also help spread the universal design. Among the studies that can be done to adopt the universal design idea in the design of public buildings in Northern Cyprus, the City Planning Department and the Chamber of Architects, which are the projects' control and approval centers, search for universal design principles in their content. Controlling public buildings' suitability for use by everyone during the design phase can be considered a method for applying universal design in these buildings and their immediate surroundings. When each public building is designed by adopting the concept of universal design with its environment, it is thought that the whole of the parts will be suitable for everyone's use.

For this proposal to be implemented, the designers should first be informed about the universal design concept. The designer can gain the information through professional development courses organized by the chamber of architects. It can be seen as a more effective method to equip designers with this knowledge before starting their professional life. During their architectural education, they know the concept of universal design without the need for vocational courses. In this context, the first step that can be made may be to open classes on the subject to include universal design in architectural education or to encourage students to research to gain knowledge on this subject. A designer who has adopted the concept of universal design must also benefit from developing technology for his creations to be suitable for everyone. For example, elevator buttons must have sensible surfaces so that visually impaired users can use elevators designed to provide vertical circulation in the building. The use of elevators with audible warning systems in buildings open to everyone's help allows visually impaired people to use the elevator more efficiently and accurately. With the universal design concept aiming to provide appropriate approach to building, circulation, and access for reaching the services in a building for everyone, public buildings will emerge for users of all ages. Remove obstacles without discriminating users with different characteristics or special needs, and offer options and solutions suitable for everyone in the same design without making a privileged design for any society segment. It has been concluded that public buildings, which will be built equally, become more functional and usable and increase their users' life quality without barriers.

\section{REFERENCES}

[1] The Center For Universal Design, "About the Center: Ronald L. Mace," NC State University-College of Design, https://projects.ncsu.edu/ncsu/design/cud/about_us/usronma ce.htm (accessed Jan. 25, 2021).

[2] WHO, "World Report On Disability", World Health Organization,

https://www.who.int/disabilities/world_report/2011/report.p df (accessed Feb. 5, 2021).

[3] M.F. Story, "The Principles of Universal Design, Universal Design Handbook," in Universal Design Handbook, 2nd ed., MGH, 2011, pp.4.3-4.12.

[4] J.P.S. Salmen, "United States Accessibility Codes and Standarts: Challanges for Universal Design" in Universal Design Handbook, 2nd ed., MGH, 2011, pp.6.1-7.1.

[5] B. Knecht, "Accessibility Regulations and a Universal Design Philosophy Inspire the Design Process," Architectural Record, AR-2004-01, pp. 145-150, 2004.

[6] Y. Liu, Y. Hou., "Notice of Retraction: "Green and Harmony Idea Study Based on the Sustainable Universal Design," The 2nd Conference on Environmental Science and Information Application Technology, Wuhan, China, 2010, pp. 9-12.

[7] A. N. Evcil, "Herkes için Tasarım Evrensel Tasarım," BY, 2011.

[8] J. Hanson., "The Inclusive City: Delivering a more Accessible Urban Environment Through Inclusive Design," International Construction Conference Responding to Change, York, September 7-8 2004, https://www.semantics cholar.org/paper/The-inclusive-city\%3A-delivering-a-more -accessible-Hanson/382c2c57da65e945ba004681aacc526b3 fca1486? sort=relevance $\&$ page $=3$ (accessed Feb. 6, 2021).

[9] Sholanke A. B., Adelowo I. E., Gbotosho J. O. , "Compliance of High-rise Buildings Vertical Accessibility Components with Universal Design Strategies: A Case Study of Covenant University, Ota, Nigeria," Civil Engineering and Architecture, Vol. 8, No. 5, pp. 735 - 749, 2020. DOI: $10.13189 /$ cea.2020.080501.

[10] Kusnierz-Krupa, D., "Historical Buildings and the Issue of their Accessibility for the Disabled", IOP Conference Series: Materials Science and Engineering, 603 (2019) 052007, doi:10.1088/1757-899X/603/5/052007

[11] Jester T. C. and S. C. Park, "Making Historic Properties Accessible, "Preservation Brief 32, National Park Service, US Department of the Interior, https://www.nps.gov/tps/ho w-to-preserve/briefs/32-accessibility.htm (accessed Mar. 4, 2021).

[12] A. N. Evcil, S. S. Yalçın Uysal, "Üsküdar Meydanı ve Engelliler İçin Erişilebilirlik," VI. Uluslararası Üsküdar Sempozyumu, 6-9 Kasim 2008, pp. 541-554.

[13] M. Kavak, "Evrensel tasarım yaklaşımı bağlamında kamusal mekânlar: Harbiye Kongre Vadisi örneği," Yüksek Lisans Tezi, Bahçeşehir Üniversitesi, İstanbul, 2010.

[14] A. Atasoy, "Kuzey Kıbrıs Türk Cumhuriyeti'nin Nüfus Coğrafyası," Mustafa Kemal Üniversitesi Sosyal Bilimler Enstitüsü Dergisi, vol 8, no.15, pp. 29-62, 2011.

[15] NDA, "Building for Everyone," Centre for Excellence in Universal Design, http://universaldesign.ie/Built-Environm ent/Building-for-Everyone/ (accessed Feb. 8, 2021).

[16] S. Goldsmith, "Universal Design," Horizontal Circulation- 
Vertical Circulation, AP, 2000, pp. 41-66.

[17] ADA, "Standards for Accessible Design," ADA-United States Department of Justice Civil Rights Division, https://www.ada.gov/.ADAstandards_index.htm (accessed Feb. 10, 2021).

[18] United Nations, "Accessibility for the disabled a design manual for a barrier free Environment," United Nations enable,

http://www.un.org/esa/socdev/enable/designm/index.html (accessed Feb. 10, 2021).

[19] Official Gazette, "Law on Disabled Persons," T.R Official Gazette-25868,

http://www.ilo.org/dyn/natlex/docs/ELECTRONIC/77387/ 96369/F229909542/TUR77387\%20English.pdf (accessed Jan. 15, 2021).

[20] TS 12576, "Şehir İçi Yollar - Kaldırım ve Yaya Geçitlerinde Ulaşılabilirlik için Yapısal Önlemler ve İşaretlemelerin
Tasarım Kuralları,” Türk Standartları Enstitüsü, 2012.

[21] TS 9111, "Özürlüler Ve Hareket Kısıtlılığı Bulunan Kişiler İçin Binalarda Ulaşılabilirlik Gerekleri,” Türk Standartları Enstitüsü, 2011.

[22] Official Gazette, "Chapter 96 - Law under Article 19 of the Streets and Buildings Regulation Law," Official Gazette-754. 29 November, 2016.

[23] K. Uzunoğlu, "Toplu konut üretiminde konut ünitesinin ön tasarım aşamasında sar metodu ile anliz değerlendirme ve test edilebilmesi için bir model," Doktora Tezi, Yakın Doğu Üniversitesi, Lefkoşa, 2014.

[24] Lefkoşa Türk Belediyesi, Kent Rehberi,https://kentrehberi.1 efkosabelediyesi.org/ (accessed Mar. 4, 2021).

[25] J. Christophersen, K. Denizou, "Guidepaths in Buildings," in Universal Design Handbook, 2nd ed., MGH, 2011, pp. 42.1-42.10. 